\title{
Analysis of the Connotation and Constructive Way of University Culture in the New Period
}

\author{
Weifeng $\mathrm{Li}^{\mathrm{a}}$, Huanning Yan ${ }^{\mathrm{b}}$ and Lixia Liang ${ }^{\mathrm{c},}$ * \\ School of Political Science and Law University of Jinan, Shandong 250022, China. \\ aliweifeng96@163.com, b1170107233@163.com, cllxia76@163.com.
}

Keywords: University culture, connotation, cultural construction.

\begin{abstract}
University culture is an important foundation and bloodline for university to survive and develop. How to deeply understand the scientific connotation of university culture, positively foster university spirit with the characteristics of the times and build university culture with individuality and features is significant and theoretical issue in the ongoing research of university theory innovation, which makes a positive difference to the development of higher education. This article mainly explains the connotation of university culture and discusses the constructive ways of university culture.
\end{abstract}

\section{Introduction}

The essence of university is a cultural institution with unique functions, which is an institution of higher education connecting the social economic and political institution with inheritance, study, integration, and innovation. It's not only a product of the development of human culture to a certain stage, but it has also gradually formed unique university culture based on the long-term schooling practice, historical accumulation, its own efforts, and the influence of the external environment. Culture is an important foundation and bloodline for university to survive and develop. Each university has its own unique university culture, and it has been identified with society through the accumulation of time and the spread of the students stepping to the society. With the development of the times and society, the advanced university culture requests continuously adding new connotations. Therefore, profoundly understanding the scientific connotation of university culture is a major theoretical issue in the ongoing research of university theory innovation, which has a positive significance for the development of higher education.

\section{The Connotation of University Culture}

Culture means the sum of spiritual and material achievements created by human beings in practice. Culture that a comprehensive reflection of ideology, values, and social systems belongs to the category of superstructure, which directly affects educational activities. University education is the highest stage of education, and university culture is a part of social culture. University culture is the sum of material and spiritual achievements created, inherited and accumulated by all teachers and students under the influence of social culture for a long time, which is also a material and spiritual wealth of school.

The concept of university culture has both narrow and broad senses. From the narrow sense, the concept of university culture focuses on the spiritual and cultural level, sometimes mutually using with the idea of the university, the dream of the university. From the broad sense, university culture regards spiritual culture, institutional culture, material and environmental culture as organic components, including several aspects such as university spiritual culture, university institutional culture, university material culture, university environmental culture and university behavior culture, which are interrelated to exist. 


\subsection{University Spiritual Culture: the Core of University Culture Construction.}

University spiritual culture is the soul and core of university culture, which is also the driving force of university construction and development. University spirit is the essence and soul of university culture reflecting the cohesion, creativity, vitality and appeal of university. The contents of the university spiritual culture mainly include three points. First, the guiding ideology and philosophy of running university; second, the university spiritual outlook, including school discipline, school spirit, study atmosphere and teaching style; and third, the university iconic representation, which mainly consists of the tradition of running university, school badges, school songs, school flags, etc. In these aspects above, mutual contact and the formation of the university spiritual culture have become the spiritual impetus for the development of the university.

\subsection{University Material Culture: Foundation of University Culture Construction.}

University material culture is the achievement and material embodiment of the university spiritual culture construction, and it is also the external performance and material basis of the university spiritual civilization. On the one hand, university culture is reflected in the ideology and direction of running school. On the other hand, it is reflected in the material construction of school. In the construction and development of universities, school leaders should attach great importance to the construction of material culture, which is a necessary measure to stabilize the teaching staff, establish good conditions for running school and ensure the quality of education. Under the guidance of spiritual culture, the construction of material culture has been promoted, in turn, the development of material culture has effectively promoted the construction of spiritual culture, which are complementary and mutually causative.

\subsection{University Institutional Culture: Guarantee of University Culture Construction.}

University institutional culture is the laws, regulations, related rules, provisions, and management regulations to maintain both the internal operation of the university and the relationship between the inside and the outside, which is mainly used to regulate various social relations in the university and plays a normative and guiding role. Institutional culture based on the common school-running concept of teachers and students is the guarantee of university culture construction. The contents of the university institutional culture primarily include four points. First, the state's laws, regulations, and policies related to higher education; second, local education laws and regulations; third, the internal rules and regulations of the school, such as teaching management institutions, personnel management institutions, campus management institutions, admissions system, post responsibility system, etc; fourth, concept system. These four aspects restrict each other and constitute an organic whole of the university institutional culture,providing institutional guarantees for the survival and development of the university.

\subsection{University Environmental Culture: External Image of University Culture Construction.}

University material culture is the "material form" culture built by university students in campus and the material condition to the survival and development of university students. Campus environment is the carrier of university culture, and the quality of campus environment directly affects the emotions and psychology of teachers and students. The clean, elegant and green environment can stimulate the sense of pride and cohesion of teachers and students. The contents of the university environmental culture include four points. First, the geographical environment of the university; second, the overall planning and layout of the university; third, the university's teaching and living facilities, architectures, campus human landscapes, afforestation and beautification, protection and use of natural ecology; fourth, the university campus culture network, audio-visual media, libraries, newspapers, magazines, and other school cultural communication carriers and facilities. These aspects are mutually interdependent and constitute the organic whole of the university environmental culture, playing an unique function in environmental education.

\subsection{University Behavior Culture: the Dynamic Embodiment of University Culture Construction.}

University behavior culture is a kind of culture that both teachers and students produce and demonstrate in learning, teaching, scientific research, management and entertainment. University 
behavior culture has particular meanings in the process of fulfilling the university mission, the process of university education is the process of teaching and learning with mutual interaction and integration, which is also a demonstration of the educators, administrators and service providers to infect and attract students in great style. The main contents of university behavior culture include four points. First, manager behavior culture; second, teacher behavior culture; third, service personnel behavior culture; fourth, student behavior culture. These aspects with interactions affect each other and jointly restrict and promote the development and improvement of student's behavior.

\section{The Way of University Culture Construction}

The construction of university culture is a purposeful behavior of the university, which origins from the cultural self-consciousness of the university students and the profound understanding of the connotation and meaning of the university. The construction of university culture generally experiences a process of gradual improvement, stereotypes and deepening. Proceeding the construction of university culture should stand at the forefront of the times, complying with the historical trend and the laws of social development, keeping a tendency of advancement for social great culture, constantly improving and deepening the contents of university culture construction, and finally forming its own cultural characteristics.

\subsection{Seriously Deal with Several Pairs of Relationships in the Construction Process.}

First, relationship between openness and selectivity. University culture is a cultural form where colleges and universities have their own characteristics in the context of international and social culture, it is influenced by social culture and also constrained by its own development rules. Higher education is the place where all kinds of ideas and cultures interweave and collide hotly. On the one hand, university culture should keep an open attitude to accept various social popular culture, on the other hand, when accepting and advocating social popular culture, university culture should also critically and selectively take the essence and discard the dregs to resist the erosion of bad thoughts and trends of thought from all sides, constantly adjust and enrich themselves.

Second, the relationship between times and advancement. Any culture is the product of the times, the generation of university culture must keep pace with the development of society, it should rather actively embrace the influence of social culture than radiate society with high-quality university culture, thus realizing the integration of social and university culture, also reflecting the features and the spirits of the times. This requires universities to closely follow the trend of the world, grasp the pulse of the times, maintain a forward-looking trend toward social culture, and constantly breed new ideas and theories as they create their own specific cultural atmosphere. This kind of oriented culture influences and promotes the development of social culture.

Third, the relationship between humanity and science. With the development of the international trend, the society requires a large number of senior talents with comprehensive qualities. It is university culture that is the best meeting point for the penetration and intersection of science and humanity. The university opens selective humanity courses, organizes students to participate in community activities, conducts science and technology competitions, etc, broadening students' knowledge, inspiring students' sense of innovation, and enhancing their humanistic qualities and scientific research capabilities.

Fourth, the relationship between pluralism and normalization. In order to improve and develop the overall quality of students, the contents and forms of university culture should be more various and colorful, effectively making up for the insufficiency of classroom teaching and enhancing the students' practical ability; while students freely develop their talents, they must also have restrictions from normative university culture. The corresponding rules and regulations formulated by the management department not only reflect the limited rights of students' freedom, but also ensure the guarantee of the healthy development of university culture. 


\subsection{Rationally Establish the Principle of University Culture Construction.}

First, the principle of cultural leadership. As the highest level of education in our country, colleges and universities have relatively concentrated on intellectuals and generally high cultural level. They are engaged in creative activities that explore new knowledge and discover laws. We must not only be satisfied with the inheritance of culture, but we must strive to create new spiritual products and cultural wealth. Taking colleges and universities as the front, the university culture with college teachers and students as the main body has certain advancement and guidance relative to the overall culture of the society. Therefore, in the construction of university culture, we must always highlight this pioneering, guard against and resist the vulgar culture, especially the negative influence of mass culture.

Second, develop the principle of synchronization. The construction of university culture is an important aspect of deepening the reform, improving the quality and efficiency of running school. The deepening of reforms provides conditions and opens channels for the construction of university culture in universities. Enhancing the quality of running school and the effectiveness of running school is the goal of university cultural construction, which both complement each other. Therefore, the construction of university culture must be based on the reform and development of the universality, and it should be carried out simultaneously with all kinds of educational reforms in the university. They can influence, infiltrate and interact with each other to ensure actual results.

Third, the principle of mechanism coordination. The construction of university culture must pay attention to the cooperation among various elements with themselves. The specific requirements are mainly reflected in the coordination of classroom and non-classroom education; the coordination of hardware and software construction; the harmonization of popularization and improvement; the coordination of era and traditional culture; the coordination between student body and teacher leadership. We must always adhere to the degree of coordination of university cultural construction as an important measure of the level of construction.

\subsection{Grasp the Links between Various Cultural Elements and Exert the Overall Benefits.}

To carry out the construction of university culture, we must stick to the principle of "system engineering", fully grasp the links and mutual promotion mechanisms among various cultural elements and bring into exerting the overall effect of cultural construction.

First, strengthen the university spiritual and cultural development.

University spiritual culture is the core element of university culture. To build an innovative university culture is the first task to strengthen the university spiritual and cultural construction. The primary task of strengthening the university spiritual and cultural construction is to determine the concept of the university, which has commonness and individuality. The commonness reflects the development law of the university, and the individuality reflects the unique tradition, the environment and conditions for running university. Each university should seriously study its own cultural tradition when it comes to forming its motto, analyze the strengths and weaknesses in school development, and basic contradictions and constraints, philosophically think the relationship between ideals and utilitarianism, spirit and value, personality and society, after weighing the pros and cons with multiple parties, they can clear their own value orientation and concept connotation.

Second, promote cultural innovation in university system.

First of all, it is necessary to strengthen the university's awareness of self-sponsorship. Under the new situation, universities should establish self-learning awareness, and under the government's macro-control, they should establish more perfect self-management, self-development, self-discipline mechanisms in enrollment, teaching, scientific research, asset management, personnel, funds, etc. Second, it is necessary to establish an academic management system. The characteristic of academic management system is that the university is dominated by academic power and non-college-type management. The scholars are protected to freely engage in academic research, which is conducive to academic innovation and the cultivation of students with innovative awareness and abilities. Third, universities should maintain the coordination between the university and society.

Third, strengthen university material/environmental culture construction. 
The material culture construction of modern universities must firstly embody the "people-oriented" education philosophy, making all kinds of facilities to present people's concern and respect. Second, it should show the characteristics of the school's positioning, research universities and education-oriented universities have differences in the function of their buildings because of their different missions. Third, they should consider the teaching model, schools that implement a full credit system must set new requirements for campus construction due to changes in students' learning and life space. Fourth, they must have iconic buildings that represent the school's personality and cultural characteristics.

Fourth, adhere to the education-oriented university behavior culture construction.

The behavior culture construction of the university should be combined with the school spirit, teaching style, style of study, and even moral construction. Each year, the school holds regular opening ceremony and graduation ceremony to represent the cultural tradition of the university. Frequent scientific and technological reports and cultural forums show the academic atmosphere of "academic freedom" and "compatibility". Elegant cultural performances show the university's cultural quality. Various social activities, scientific and technological innovation activities are also extremely modern educational features; The "volunteer activities for the country people" activities and social practice activities of science and technology, health, and culture on vacations, as well as the construction of various quality education bases, will vividly transfer university culture to society.

\section{Summary}

In short, development is the eternal theme of the university. If universities want to make a difference in the new period and achieve greater and sustainable development, they must establish a correct view of university culture and use this as a guide, based on their own reality, and on the basis of constant summary, exploration and refinement, they will actively cultivate the spirit of the university with the characteristics of the times and build university culture with individual characteristics.

The generation of university culture is a long-term and complex project. It not only needs to reflect the spiritual outlook of the times, but also depends on the support of internal policies and institutions of the university. It is necessary to closely combine the two above to achieve healthy and orderly development, thus enhancing the overall level of Chinese university culture, continually promoting the higher education and the entire social, political, economic, and culture to stably, orderly and healthily go forward.

\section{Acknowledgements}

This work was financially supported by Shandong Graduate Education Innovation Program fund (SDYY16018).

\section{References}

[1]. Quid Wu. University President and University Culture. Chinese University Teaching. Vol.12 (2003), p. 4-5.

[2]. Qi a Xiao. Research on the connotation of university culture and its related factors. Forum on Contemporary Education, .Vol.165 (2009), No.8, p.91-93.

[3]. Shaman Wang. Analysis of the Connotation. Features and Functions of University Culture. China Higher Education Research.Vol.5 (2008), p.66-67.

[4]. Ying Sun. The connotation and construction of university culture in the new era. Studies in Polytechnic Higher Education.Vol.05 (2003), p.86-87. 
[5]. Jibing Wang, Wendi Chu. Some thoughts of strengthening university culture construction. Journal of Liaoyang Agricultural College. Vol.04 (2004), p. 68-70.

[6]. Zinging Zhang .The Construction of University Culture. Journal of Shandong University of Technology. Vol.02 (2004), p.10-13. 